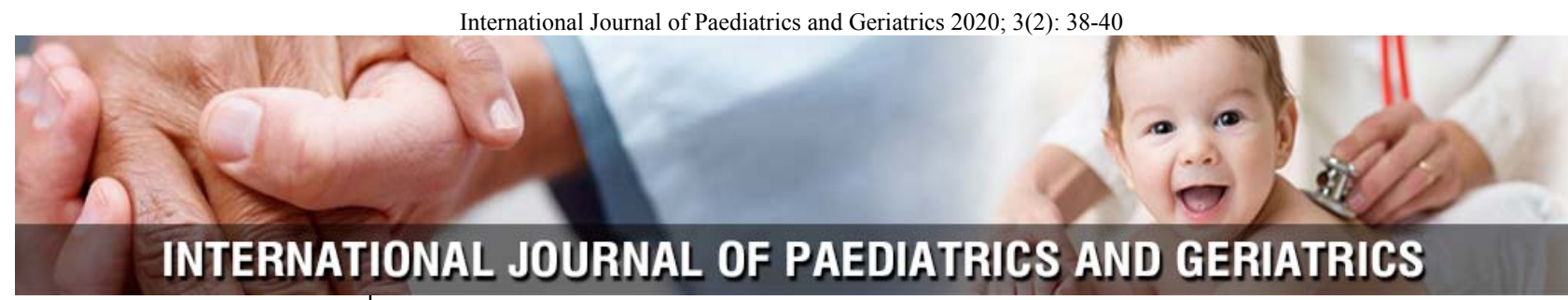

P-ISSN: 2664-3685

E-ISSN: 2664-3693

IJPG 2020; 3(2): 38-40

Received: 10-05-2020

Accepted: 20-06-2020

Dr. Hitender

M.O. Civil Hospital Rajgrah

Simour Himachal Pradesh,

India

Dr. Kiran

Junior Resident, Department

of Pediatrics, IGMC Shimla,

Himachal Pradesh, India

Dr. Himanshu

Junior Resident, Department

of Pediatrics, IGMC Shimla

Himachal Pradesh, India
Corresponding Author:

Dr. Himanshu

Junior Resident, Department

of Pediatrics, IGMC Shimla

Himachal Pradesh, India

\section{Association between thyroid profile and serum bilirubin levels in term neonates on day 3 of life}

\author{
Dr. Hitender, Dr. Kiran and Dr. Himanshu \\ DOI: $\underline{\text { https://doi.org/10.33545/26643685.2020.v3.i2a.89 }}$
}

\section{Abstract}

Background: The present study was conducted to correlate thyroid profile and serum bilirubin levels assessed in term neonates on day 3 of life.

Materials \& Methods: The present study was conducted on146 neonate's $\geq 37$ weeks of gestational age of both genders. Birth weight, gestational age, thyroid profile (T3, T4, TSH), serum bilirubin level (SBR) was calculated.

Results: The mean gestational age was 272.4 days, birth weight was $2.8 \mathrm{Kgs}$, total bilirubin was 11.35 $\mathrm{mg} / \mathrm{dl}$, direct bilirubin was $0.46 \mathrm{mg} / \mathrm{dl}$, fT3 level was $8.24 \mathrm{pg} / \mathrm{ml}$, fT4 was $2.18 \mathrm{ng} / \mathrm{dl}$ and TSH was 4.08 $\mathrm{mlU} / \mathrm{ml}$. Normal expected neonates had normal T3, T4, TSH, TSB and direct Bilirubin level whereas 4 neonates had T3 level that ranged from 94- 109, T4 from 5.8- 8.2, TSH from 11.2- 13.94, TSB from 10.2- 16.2 and direct bilirubin from 0.31- 0.54.

Conclusion: Authors found no significant association between serum TSH and SBRT in term neonates.

Keywords: bilirubin, neonate, thyroid

\section{Introduction}

Neonatal indirect hyperbilirubinemia $(\mathrm{NNH})$ is a common clinical scenario manifesting as jaundice in the first week of life. NNH manifests with physical findings such as yellowish discoloration of the skin and sclera in newborns is due to accumulation of unconjugated bilirubin. However, unconjugated hyperbilirubinemia usually reflects a normal physiological phenomenon in most neonates ${ }^{[1]}$.

Hyperbilirubinemia is the commonest finding in the first week of life. It is a cause of concern for the parents as well as for the pediatricians and source of anxiety to parents. To the pediatrician jaundice remains the most common and perhaps the most vexing problem in the well-baby nursery ${ }^{[2]}$. Jaundice is observed during the first week of life in approximately $60 \%$ of term infants and $80 \%$ of preterm infants. Jaundice usually becomes apparent in a cephalocaudal progression, starting on the face and progressing to abdomen and then the feet, as serum level increase. The yellow color usually results from the accumulation of unconjugated, non-polar, lipid soluble bilirubin pigment in the skin formed from hemoglobin and non-enzymatic reducing agents in the reticulo- endothelial cells ${ }^{[3]}$.

Bilirubin production is 2-3 times higher in normal term newborns compared with adults. Unconjugated (indirect) hyperbilirubinemia occurs as a result of excessive bilirubin formation and because the neonatal liver cannot clear bilirubin rapidly enough from the blood ${ }^{[4]}$. Under normal circumstances, the level of indirect reacting bilirubin in umbilical cord serum is $1-3 \mathrm{mg} / \mathrm{dl}$ and rises at a rate of less than $5 \mathrm{mg} / \mathrm{dl} / 24 \mathrm{hrs}$. Thus jaundice becomes visible on the 2 nd- 3 rd day (36-72hrs) usually peaking by the $3 \mathrm{rd}$ day at $5-6 \mathrm{mg} / \mathrm{dl}$ and decreasing to below $2 \mathrm{mg} / \mathrm{dl}$ between 5 th and 7 th day of life ${ }^{[5]}$. The present study was conducted to correlate thyroid profile and serum bilirubin levels assessed in term neonates on day 3 of life.

\section{Materials and Methods}

The present study was conducted in the department of Pediatrics. It comprised of 146 neonate's $\geq 37$ weeks of gestational age of both genders. The study was approved from institutional ethical committee. All parents were informed regarding the study and their consent was obtained. 
Particulars of patients such as name, age, gender etc. was recorded. Birth weight, gestational age, Thyroid Profile (T3, T4, TSH), serum bilirubin level (SBR) was calculated. Results were tabulated and subjected to statistical analysis.
$\mathrm{P}$ value less than 0.05 was considered significant.

\section{Results}

Table 1: Assessment of parameters

\begin{tabular}{|c|c|c|}
\hline Parameters & Mean & SD \\
\hline Gestational age (Days) & 272.4 & 6.42 \\
\hline Birth weight (Kgs) & 2.8 & 3.2 \\
\hline Total bilirubin (mg/dl) & 11.35 & 0.12 \\
\hline Direct bilirubin (mg/dl) & 0.46 & 2.6 \\
\hline fT3 (pg/ml) & 8.24 & 1.5 \\
\hline fT4 (ng/dl) & 2.18 & 3.02 \\
\hline TSH (mlU/ml) & 4.08 & \\
\hline
\end{tabular}

Table I shows that mean gestational age was 272.4 days, birth weight was $2.8 \mathrm{Kgs}$, total bilirubin was $11.35 \mathrm{mg} / \mathrm{dl}$, direct bilirubin was $0.46 \mathrm{mg} / \mathrm{dl}$, fT3 level was $8.24 \mathrm{pg} / \mathrm{ml}$, fT4 was $2.18 \mathrm{ng} / \mathrm{dl}$ and TSH was $4.08 \mathrm{mlU} / \mathrm{ml}$.

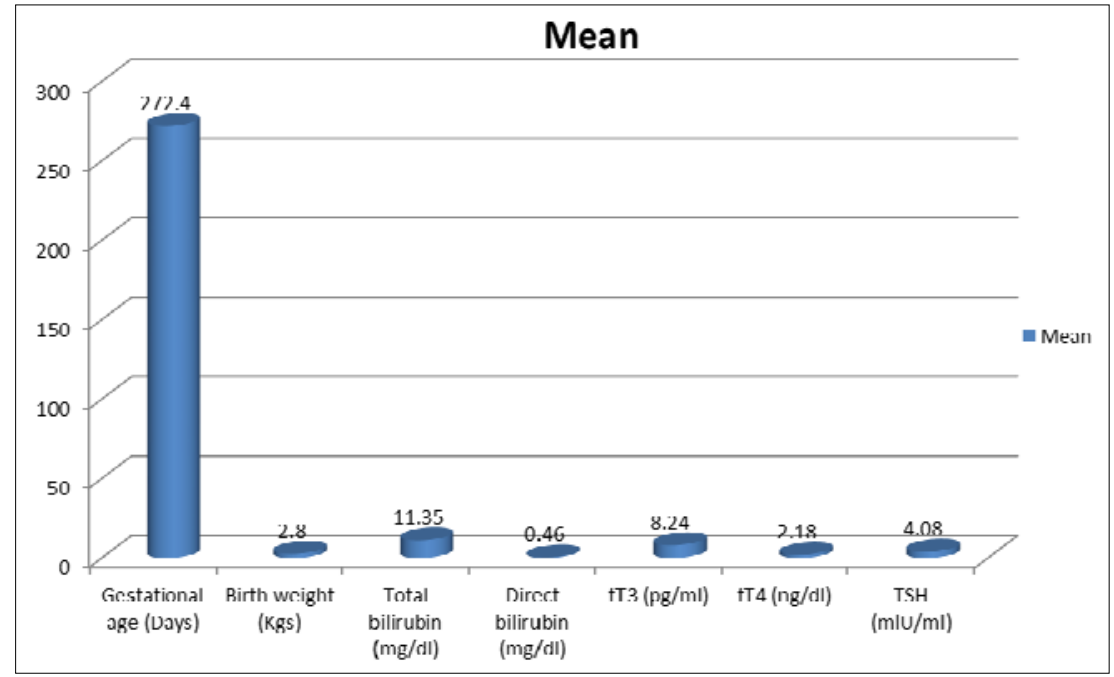

Graph 1: Assessment of parameters

Table 2: Laboratory parameters of neonates with abnormal thyroid profile

\begin{tabular}{|c|c|c|c|c|c|}
\hline & T3 & T4 & TSH & $\begin{array}{c}\text { Total serum } \\
\text { bilirubin }\end{array}$ & $\begin{array}{c}\text { Direct } \\
\text { bilirubin }\end{array}$ \\
\hline $\begin{array}{c}\text { Normal } \\
\text { expected }\end{array}$ & $1.4-4.6$ & $0.8-2.1$ & $<10$ & $<15$ & $<0.52$ \\
\hline Neonate 1 & 109 & 8.2 & 13.94 & 10.2 & 0.31 \\
\hline Neonate 2 & 102 & 7.4 & 13.2 & 16.5 & 0.52 \\
\hline Neonate 3 & 98 & 6.5 & 12.5 & 15.8 & 0.46 \\
\hline Neonate 4 & 94 & 5.8 & 11.2 & 16.2 & 0.54 \\
\hline
\end{tabular}

Table II shows that normal expected neonates had normal T3, T4, TSH, TSB and direct Bilirubin level whereas 4 neonates had T3 level that ranged from 94-109, T4 from 5.8- 8.2, TSH from 11.2- 13.94, TSB from 10.2- 16.2 and direct bilirubin from $0.31-0.54$.

\section{Discussion}

Immature newborn brain is susceptible to toxicity from unconjugated bilirubin, resulting in neuro developmental or intellectual handicaps and finally frank kernicterus ${ }^{[6]}$. Hence early detection and appropriate management of neonatal jaundice is of paramount importance in preventing kernicterus. While jaundice per se is not preventable none the less early detection of threatening bilirubin levels permit initiation of phototherapy and prevents higher risk and high cost exchange transfusion therapy or kernicterus ${ }^{[7]}$. The AAP (American Academy of Pediatrics) recommends that newborns discharged before or within 48 hours, should have a follow-up visit after 2-3 days to detect significant jaundice and other problems. In India stays of 24-48 hours are now common practice. Several studies suggest that neonatal hyperbilirubinemia is the most common cause for readmission of healthy term babies discharged early. In up to $4 \%$ of term newborns who are readmitted to the hospital during their first week of life, approximately $85 \%$ are readmitted for jaundice ${ }^{[8]}$.

$\mathrm{CH}$ is a well-known cause of prolonged unconjugated hyperbilirubinemia and appears to be associated with the delayed maturation of hepatic uridine diphosphate glucosyl transferase (UDPGT) enzyme activity ${ }^{[9]}$. Since thyroid hormones act on almost all tissues of the body and influence enzyme concentration and activity, the metabolism of substrates, vitamins and mineral salts, basal metabolism, or calorigenesis; they also stimulate oxygen consumption and act in other endocrine systems ${ }^{[10]}$. The present study was conducted to correlate thyroid profile and serum bilirubin levels assessed in term neonates on day 3 of life.

In present study we found that mean gestational age was 272.4 days, birth weight was $2.8 \mathrm{Kgs}$, total bilirubin was $11.35 \mathrm{mg} / \mathrm{dl}$, direct bilirubin was $0.46 \mathrm{mg} / \mathrm{dl}$, fT3 level was $8.24 \mathrm{pg} / \mathrm{ml}$, fT4 was $2.18 \mathrm{ng} / \mathrm{dl}$ and TSH was $4.08 \mathrm{mlU} / \mathrm{ml}$. 
Kadambi et al. ${ }^{[11]}$ in their study correlated thyroid Profile and serum bilirubin levels assessed in term neonates at 72 hours of life on 105 term neonates born through cesareansection. The mean gestational age of the study population was $268.05 \pm 6.25$ days, and mean birth weight was $2.997 \pm 0.36 \mathrm{kgs}$. The mean serum levels of total bilirubin were $11.36 \pm 3.52 \mathrm{mg} / \mathrm{dl}$. The mean serum fT3, fT4, TSH levels were $8.17 \pm 23.2 \mathrm{pg} / \mathrm{ml}, 2.16 \pm 1.68 \mathrm{ng} / \mathrm{dl}$ and $4.07 \pm 3.4$ $\mathrm{mIU} / \mathrm{ml}$ respectively. A positive association was noted between serum TSH and total serum bilirubin $(r=0.176, p=$ 0.067 ) but not statistically significant.

We found that normal expected neonates had normal T3, T4, TSH, TSB and direct Bilirubin level whereas 4 neonates had T3 level that ranged from 94- 109, T4 from 5.8- 8.2, TSH from 11.2- 13.94, TSB from 10.2- 16.2 and direct bilirubin from $0.31-0.54$. Sriram et al. ${ }^{[12]}$ found that newborns who developed significant hyperbilirubinemia male: female ratio was $1.07: 1.9(33 \%)$ newborns with significant hyperbilirubinemia had jaundice in previous siblings. In the present study, the value of $4.9 \mathrm{mg} / \mathrm{dl}$ was determined to have the best combination of sensitivity and specificity to predict neonates at risk of hyper bilirubinemia subsequently. At this value of $4.9 \mathrm{mg} / \mathrm{dl}$ there is high sensitivity and a very high negative predictive value, although a low positive predictive value for predicting neonates likely to develop significant hyperbilirubinemia. Early screening and appropriate management of hyperbilirubinemia is needed for prevention of complications in the newborn. This decreases the significant burden of untreated severe neonatal jaundice, causing potential neurological sequelae. Prediction of neonatal hyperbilirubinemia has widespread implication especially in our country where there are limited resources.

The shortcoming of the study is small sample size.

\section{Conclusion}

Authors found no significant association between serum TSH and SBRT in term neonates.

\section{References}

1. Mishra S, Agarwal R, Deorari AK, Paul VK. Jaundice in the newborns. Indian J Pediatr. 2008; 75(2):157-63.

2. Gartner LM, Sun Lee K, Vaisman S, Lane D, Zarafu I. Development of bilirubin transport and metabolismin the newborn rhesus monkey. J Pediatr. 1977; 90(4):513-531.

3. Bhutani VK, Zipursky A, Blencowe H, Khanna R, Sgro $\mathrm{M}$, Ebbesen $\mathrm{F}$ et al. Neonatal hyperbilirubinemia and Rhesus disease of the newborn: incidence and impairment estimates for 2010 at regional and global levels. Pediatr Res. 2013; 74(S1):86-100.

4. Das S, Van Landeghem F. Clinicopathological Spectrum of Bilirubin Encephalopathy/Kernicterus. Diagnostic. 2019; 9(1):24-24.

5. Rastogi MV, LaFranchi SH. Congenital hypothyroidism OJRD. Orphanet J Rare Dis. 2010; 17(5):1750-1772.

6. Desai MP, Sharma R, Riaz I, Sudhanshu S, Parikh R, Bhatia V. Newborn Screening for Congenital Hypothyroidism: Recommended Guidelines. Indian J Pediatr. 2018; 85(6):440-447.

7. Mullur R, Liu YY, Brent GA. Thyroid Hormone Regulation of Metabolism. Physiol Rev. 2014; 94(2):355-382.
8. Singh B, Ezhilarasan R, Kumar P, Narang A. Neonatal hyperbilirubinemia and its association with thyroid hormone levels and urinary iodine excretion. Indian $\mathbf{J}$ Pediatr. 2003; 70:311-315.

9. Lee KS, Perlman M, Ballantyne M, Elliott I, To T. Association between duration of neonatal hospital stay and readmission rate. J pediatr. 1995; 127(5):758-66.

10. Kiely M, Drum MA, Kessel W. Early discharge, risks, benefits and who decides. Clinperinatol. 1998; 25:53953.

11. Kadambi P, Ramprakash MA, Soujanya G, Reddy LSP. Association between Thyroid Profile and Serum Bilirubin Levels in Term Neonates on Day 3 of Life. Asian J Clin. Pediatr. Neonatol. 2020; 8(2):42-45.

12. Sriram G, Paramahamsa RRK. Predictive value of serum bilirubin level for identifying term neonates at risk for subsequent hyperbilirubinemia. Int J Contemp Pediatr. 2019; 6:1914-21. 